Atmos. Chem. Phys., 19, 11267-11278, 2019

https://doi.org/10.5194/acp-19-11267-2019

(C) Author(s) 2019. This work is distributed under

the Creative Commons Attribution 4.0 License.

\title{
Ozone enhancement due to the photodissociation of nitrous acid in eastern China
}

\author{
Xuexi Tie ${ }^{1,2,3}$, Xin Long ${ }^{1,5}$, Guohui $\mathbf{L i}^{1}$, Shuyu Zhao ${ }^{1}$, Junji Cao ${ }^{1}$, and Jianming $\mathbf{X u}^{2,4}$ \\ ${ }^{1}$ KLACP, SKLLQG, Institute of Earth Environment, Chinese Academy of Sciences, Xi' an 710061, China \\ ${ }^{2}$ Shanghai Typhoon Institute, Shanghai Meteorological Service, Shanghai 200135, China \\ ${ }^{3}$ Center for Excellence in Urban Atmospheric Environment, Institute of Urban Environment, \\ Chinese Academy of Sciences, Xiamen 361021, China \\ ${ }^{4}$ Shanghai Key Laboratory of Meteorology and Health, Shanghai 200030, China \\ ${ }^{5}$ School of Environment Science and Engineering, Southern University of Science and Technology, \\ Shenzhen 518055, China
}

Correspondence: Xuexi Tie (tiexx@ieecas.cn) and Jianming Xu (metxujm@163.com)

Received: 12 April 2019 - Discussion started: 25 April 2019

Revised: 13 August 2019 - Accepted: 14 August 2019 - Published: 6 September 2019

\begin{abstract}
PM}_{2.5}$, particulate matter with a diameter of $2.5 \mu \mathrm{m}$ or less, is one of the major components of air pollution in eastern China. In the past few years, China's government has made strong efforts to reduce $\mathrm{PM}_{2.5}$ pollution. However, another important pollutant (ozone) is becoming a problem in eastern China. Ozone $\left(\mathrm{O}_{3}\right)$ is produced by photochemistry, which requires solar radiation for the formation of $\mathrm{O}_{3}$. Under heavy $\mathrm{PM}_{2.5}$ pollution, solar radiation is often depressed, and the photochemical production of $\mathrm{O}_{3}$ is prohibited. This study shows that during late spring and early fall in eastern China, under heavy $\mathrm{PM}_{2.5}$ pollution, there was often strong $\mathrm{O}_{3}$ photochemical production, causing a co-occurrence of high $\mathrm{PM}_{2.5}$ and $\mathrm{O}_{3}$ concentrations. This co-occurrence of high $\mathrm{PM}_{2.5}$ and $\mathrm{O}_{3}$ is unusual and is the main focus of this study. Recent measurements show that there were often high HONO surface concentrations in major Chinese megacities, especially during daytime, with maximum concentrations ranging from 0.5 to $2 \mathrm{ppbv}$. It is also interesting to note that high HONO concentrations occurred during high aerosol concentration periods, suggesting that there were additional HONO surface sources in eastern China. Under high daytime HONO concentrations, HONO can be photodissociated to $\mathrm{OH}$ radicals, which enhance the photochemical production of $\mathrm{O}_{3}$. In order to study the above scientific issues, a radiative transfer model (TUV; tropospheric ultraviolet-visible) is used in this study, and a chemical steady-state model is established to calculate $\mathrm{OH}$ radical
\end{abstract}

concentrations. The calculations show that by including the $\mathrm{OH}$ production of photodissociated HONO, the calculated $\mathrm{OH}$ concentrations are significantly higher than the values without including this production. For example, by including HONO production, the maximum $\mathrm{OH}$ concentration under high aerosol conditions $(\mathrm{AOD}=2.5)$ is similar to the value under low aerosol conditions $(\mathrm{AOD}=0.25)$ in the no-HONO case. This result suggests that even under high aerosol conditions, the chemical oxidizing process for $\mathrm{O}_{3}$ production can occur, which explains the co-occurrence of high $\mathrm{PM}_{2.5}$ and high $\mathrm{O}_{3}$ in late spring and early fall in eastern China. However, the $\mathrm{O}_{3}$ concentrations were not significantly affected by the appearance of HONO in winter. This study shows that the seasonal variation of solar radiation plays important roles for controlling the $\mathrm{OH}$ production in winter. Because solar radiation is at a very low level in winter, adding the photolysis of HONO has a smaller effect in winter than in other seasons, and $\mathrm{OH}$ remains at low values by including the HONO production term. This study provides some important scientific insight to better understand $\mathrm{O}_{3}$ pollution in eastern China. 


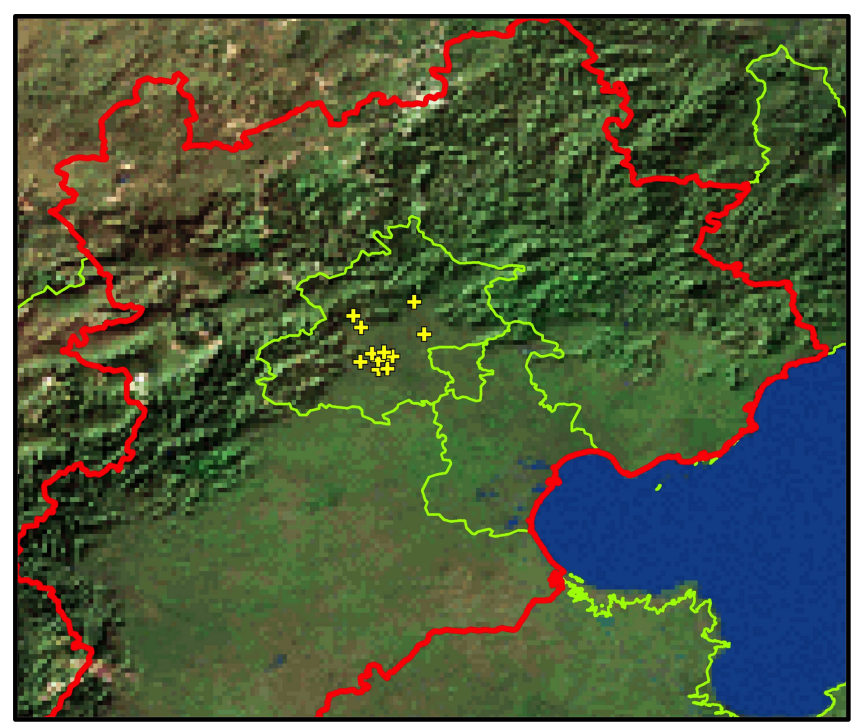

Figure 1. The geographic locations of the measurement sites in Beijing, from which the measured concentrations of $\mathrm{PM}_{2.5}$ and $\mathrm{O}_{3}$ are used in the analysis.

\section{Introduction}

Currently, China is undergoing rapid economic development, resulting in a higher demand for energy and greater use of fossil fuels. As a result, high emissions of pollutants produce heavy pollution in the megacities of eastern China, such as Beijing and Shanghai. For example, in the city of Shanghai (a large megacity in China), urban and economic developments of the city are very rapid. During 1990 to 2015, the population increased from 13.3 to 24.1 million. The number of automobiles increased from 0.2 million (1993) to 2.0 million (2011). The rapidly growing population and energy usage caused a rapid increase in the emissions of pollutants, leading to severe air pollution problems in these megacities (Zhang et al., 2006; Geng et al., 2007; Deng et al., 2008).

Measurements such as satellite observations have revealed much higher aerosol pollution in eastern China than in the eastern US (Tie et al., 2006). High aerosol pollution causes a wide range of environmental consequences. Jia et al. (2019) studied anthropogenic aerosol pollution over the eastern slope of the Tibetan Plateau, and Zhu et al. (2018) studied the impact of smoke aerosols from Russian forest fires on the air pollution over Asia. According to a study by Tie et al. (2009a), exposure to extremely high particle concentrations leads to a great increase in lung cancer cases. High PM (particular matter) concentrations also significantly reduce the range of visibility in China's megacities (Deng et al., 2008). According to a recent study, high aerosol pollution causes important effects on crop (rice and wheat) production in eastern China (Tie et al., 2016).

In the troposphere, ozone formation results from a complicated chemical process and requires ozone precursors, such

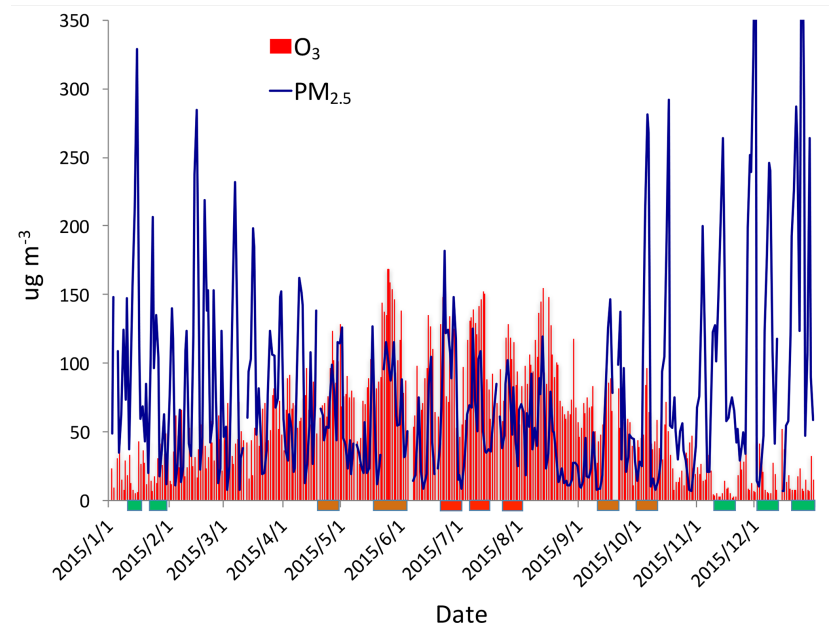

Figure 2. The daily averaged concentrations of $\mathrm{PM}_{2.5}$ and $\mathrm{O}_{3}$ in the Beijing region in 2015. The concentrations are averaged over all sites shown in Fig. 1. The blue lines represent the $\mathrm{PM}_{2.5}$ concentrations $\left(\mu \mathrm{g} \mathrm{m}^{-3}\right)$, and the red bars represent the $\mathrm{O}_{3}$ concentrations $\left(\mu \mathrm{g} \mathrm{m}^{-3}\right)$. The rectangles show some typical events during winter (green), spring and fall (orange), and summer (red).

as VOCs (volatile organic carbons) and $\mathrm{NO}_{x}=\mathrm{NO}+\mathrm{NO}_{2}$ (nitrogen oxides) (Sillman, 1995). With the increase in industrial activity and the number of automobiles, the precursors of ozone $\left(\mathrm{O}_{3}\right)$ and the global budget of oxidization are also significantly increased (J. P. Huang et al., 2017, 2018). As a result, $\mathrm{O}_{3}$ pollution is becoming a serious pollution problem in Shanghai and other Chinese megacities (Geng et al., 2010; Tie et al., 2009b, 2015). The effects of the $\mathrm{O}_{3}$ production rate can be characterized as either $\mathrm{NO}_{x}$-sensitive or VOC-sensitive conditions. For city areas, $\mathrm{O}_{3}$ production is generally VOC-sensitive, while in remote areas, $\mathrm{O}_{3}$ production is generally $\mathrm{NO}_{x}$-sensitive in eastern China (Sillman, 1995; Zhang et al., 2003; Lei et al., 2004; Tie et al., 2013). Thus, better understanding the trends of $\mathrm{O}_{3}$ precursors (VOCs, $\mathrm{NO}_{x}$ ) is important to determine the $\mathrm{O}_{3}$ trends in Shanghai (as well as many large cities in China).

In the past few years, China's government has made strong efforts to reduce $\mathrm{PM}_{2.5}$ pollution. However, another important pollutant $\left(\mathrm{O}_{3}\right)$ is becoming a problem in eastern China. Several studies regarding $\mathrm{O}_{3}$ formation have been previously conducted in Shanghai. For example, Geng et al. (2007, 2008) studied the relationship between $\mathrm{O}_{3}$ precursors $\left(\mathrm{NO}_{x}\right.$ and VOCs) for ozone formation in Shanghai. Tie et al. (2009) studied the short-term variability of $\mathrm{O}_{3}$ in Shanghai. Their study suggested that in addition to ozone precursors, meteorological conditions, such as regional transport, also have strong impacts on ozone concentrations. During September 2009, a major field experiment (MIRAGE-Shanghai) was conducted in Shanghai, and multiple chemical species were measured during the experiment. The summary of the measurements by Tie et al. (2013) suggests that ozone formation 

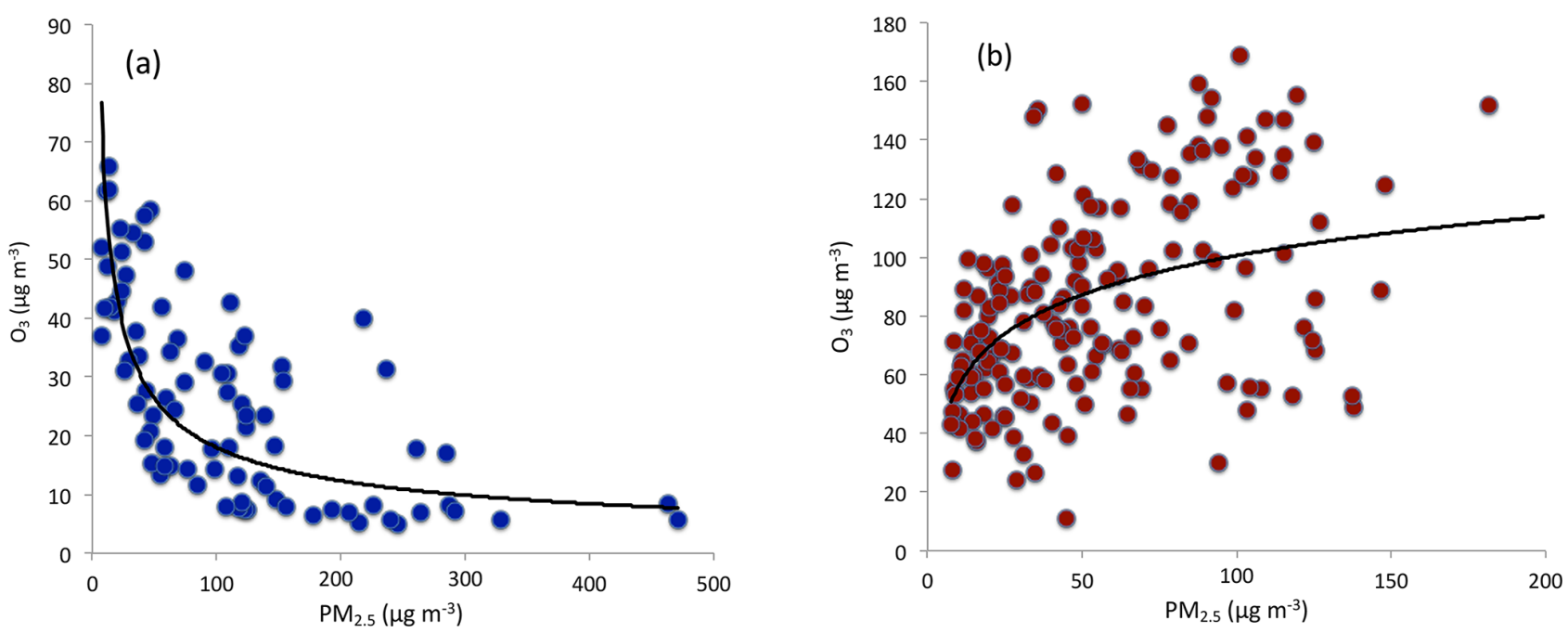

Figure 3. The correlation between $\mathrm{O}_{3}$ and $\mathrm{PM}_{2.5}$ concentrations during winter (a) and from late spring to early fall (b). During winter, $\mathrm{O}_{3}$ concentrations were strong anticorrelated with $\mathrm{PM}_{2.5}$ concentrations. From late spring to early fall, $\mathrm{O}_{3}$ concentrations were correlated with $\mathrm{PM}_{2.5}$ concentrations.

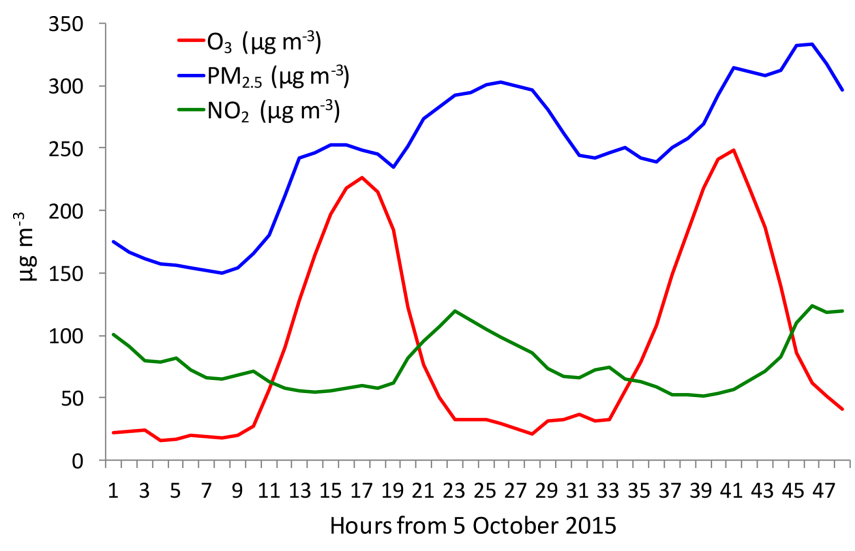

Figure 4. The diurnal variations of $\mathrm{PM}_{2.5}$ (blue line), $\mathrm{O}_{3}$ (red line), and $\mathrm{NO}_{2}$ (green line) during a fall period (from 5 to 6 October 2015). It shows that under high $\mathrm{PM}_{2.5}$ conditions, there was a strong $\mathrm{O}_{3}$ diurnal variation.

in Shanghai is under VOC-sensitive conditions. However, if the emission ratio of $\mathrm{NO}_{x} / \mathrm{VOCs}$ is reduced to a lower value $(0.1-0.2)$, the ozone formation in Shanghai will switch from VOC-sensitive conditions to $\mathrm{NO}_{x}$-sensitive conditions.

Despite the fact that some progress has been made for ozone formation in megacities in China, there is still a lack of studies on ozone development in large cities of China. For example, this study shows that during late spring and early fall in eastern China, under heavy $\mathrm{PM}_{2.5}$ pollution, there was often strong $\mathrm{O}_{3}$ chemical production, causing the co-occurrence of high $\mathrm{PM}_{2.5}$ and $\mathrm{O}_{3}$ concentrations. Under heavy aerosol conditions, solar radiation is depressed, significantly reducing the photochemical production of $\mathrm{O}_{3}$. This co-occurrence of high $\mathrm{PM}_{2.5}$ and $\mathrm{O}_{3}$ is unusual and is the focus of this study. He and Carmichael (1999) suggest that aerosol particles can enhance the scattering of solar radiation, enhancing the flux density inside the boundary layer. Recent measurements also show that there were often high HONO concentrations in major Chinese megacities, especially during daytime, with maximum concentrations ranging from 0.5 to 2 ppbv (Huang et al., 2017). Zhang et al. (2016) suggest that there are several potential HONO sources, including surface emissions and conversion of $\mathrm{NO}_{2}$ at the ocean surface, and adding these sources can improve the calculated HONO concentrations. It is also interesting to note that high HONO surface concentrations occurred during high aerosol concentration periods, suggesting that there are additional HONO surface sources in eastern China. Under high daytime HONO concentrations, $\mathrm{HONO}$ can be photodissociated to $\mathrm{OH}$ radicals, which enhance the photochemical production of $\mathrm{O}_{3}$.

The paper is organized as follows: in Sect. 2, we describe the measurement of $\mathrm{O}_{3}$ and $\mathrm{PM}_{2.5}$. In Sect. 3, we describe the calculation of the photodissociation rate of HONO, a steady-state model for the calculation of $\mathrm{OH}$, and the causes of high $\mathrm{O}_{3}$ production under heavy aerosol conditions. Section 4 shows a brief conclusion of the results.

\section{Measurements of $\mathrm{O}_{3}$ and $\mathrm{PM}_{2.5}$}

There are long-term measurements in eastern China by the Chinese Environment Protection Agency (CEPA) for monitoring the air quality in China. In eastern China, especially in the capital city of China (Beijing), there is often heavy air pollution, particularly fine particular matter $\left(\mathrm{PM}_{2.5}\right.$ - the radius of particles being less than $2.5 \mu \mathrm{m}$ ). Figure 1 shows the measurement sites in Beijing, from which the measured concentrations of $\mathrm{PM}_{2.5}$ and $\mathrm{O}_{3}$ are used in the analysis. In the 


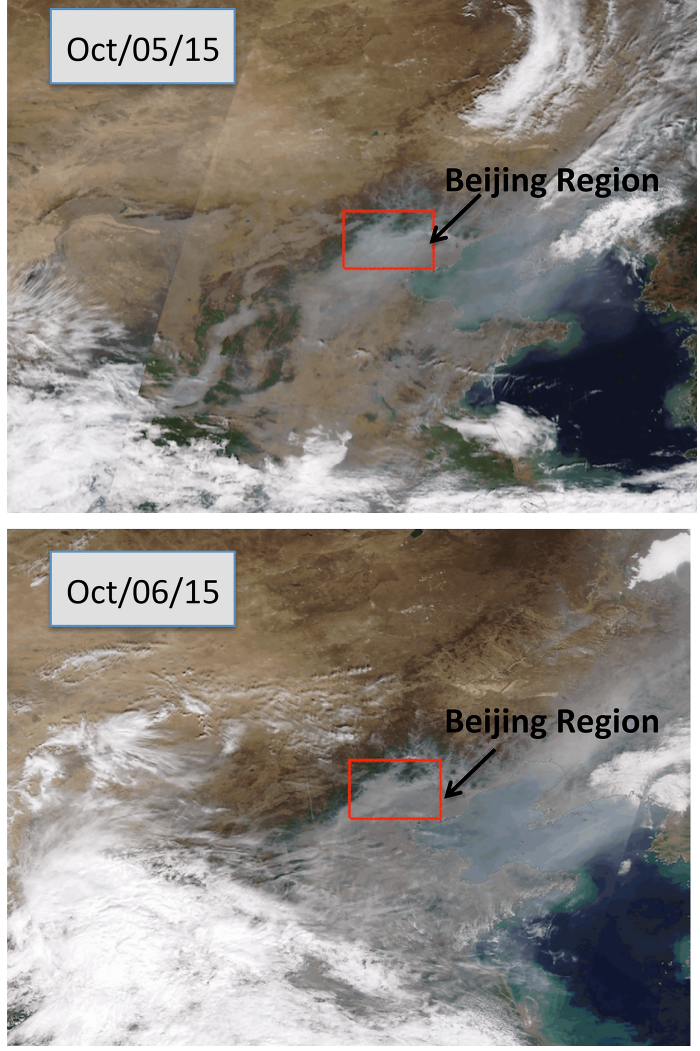

Figure 5. The cloud conditions during the period of the case study (between 5 and 6 October 2015) in the Beijing region. Bright white shows the cloud cover, and grey-white shows the haze cover. The Beijing region was under heavy haze conditions during the period. The figure is download from https://worldview.earthdata.nasa.gov (last access: 15 July 2019), with additions.

region, the air pollution was very heavy, especially in winter (Long et al., 2016; Tie et al., 2017). Previous studies suggest that both aerosol and $\mathrm{O}_{3}$ have become major pollutants in the region (Li et al., 2017).

Figure 2 shows the daily averaged concentrations of $\mathrm{PM}_{2.5}$ and $\mathrm{O}_{3}$ in the Beijing region in 2015. The daily averaged concentrations show that there were strong daily and seasonal variations for the concentrations of both $\mathrm{PM}_{2.5}$ and $\mathrm{O}_{3}$. Despite the daily variation, the concentrations of $\mathrm{PM}_{2.5}$ exhibited a strong seasonal variation. For example, there were very high concentrations during winter, with a maximum of $\sim 300 \mu \mathrm{g} \mathrm{m}^{-3}$, while in summer, the maximum concentrations were reduced to $\sim 150 \mu \mathrm{g} \mathrm{m}^{-3}$. The seasonal variability of $\mathrm{O}_{3}$ concentrations were opposite to the $\mathrm{PM}_{2.5}$ concentrations, with lower concentrations in winter $\left(<50 \mu \mathrm{g} \mathrm{m}^{-3}\right)$ and higher concentrations in summer $\left(>150 \mu \mathrm{g} \mathrm{m}^{-3}\right)$. These seasonal variations of $\mathrm{PM}_{2.5}$ and $\mathrm{O}_{3}$ have been studied by previous authors (Tie and Cao, 2017; Li et al., 2017). Their results suggest that high winter $\mathrm{PM}_{2.5}$ concentrations resulted from the combination of high emissions (heating season in the Beijing region) and poor meteorological ventilation conditions,
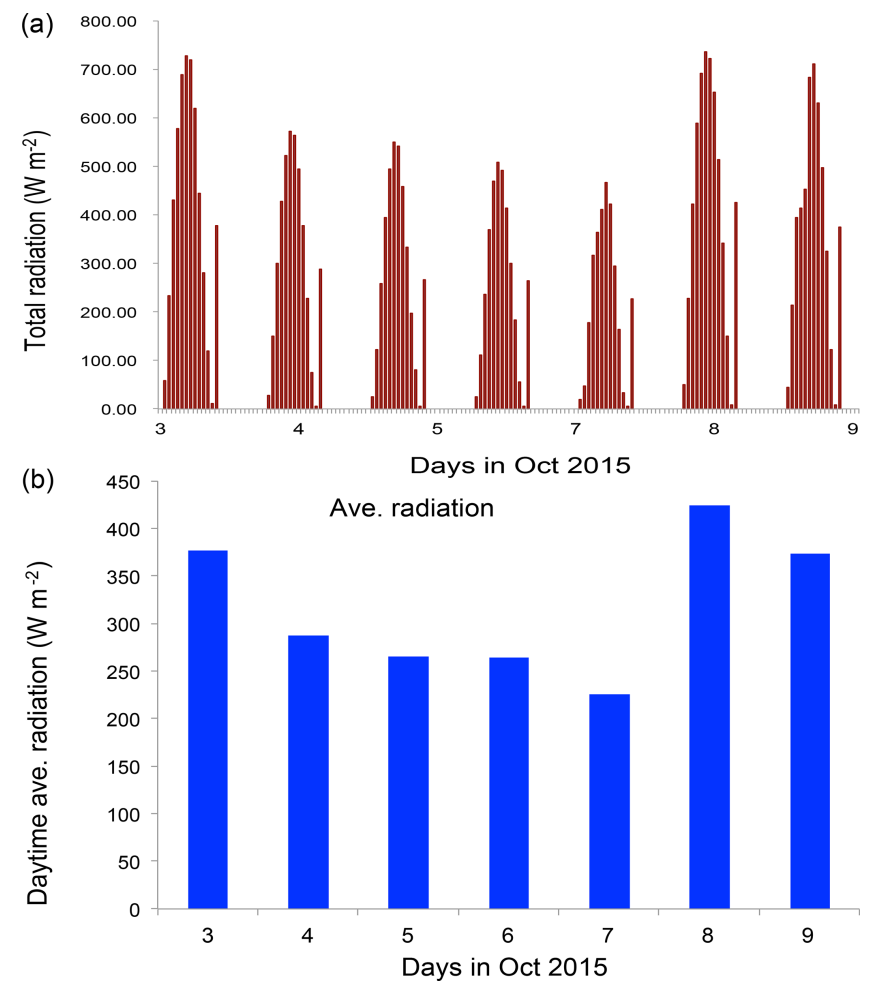

Figure 6. The measured solar radiation $\left(\mathrm{W} \mathrm{m}^{-2}\right)$ from 3 to 9 October 2015 in Beijing. (a) Hourly values and (b) daytime averaged values.

such as a lower PBL (planetary boundary layer) height (Quan et al., 2013; Tie et al., 2015). According to the photochemical theory of $\mathrm{O}_{3}$ formation, high summer and low winter $\mathrm{O}_{3}$ concentrations are mainly due to the seasonal variation of solar radiation (Seinfeld and Pandis, 2006).

Heavy aerosol concentrations play important roles in reducing solar radiation, causing the reduction of $\mathrm{O}_{3}$ formation (Bian et al., 2007). As we show in Fig. 3a, during wintertime, the $\mathrm{O}_{3}$ concentrations were strongly anticorrelated with the $\mathrm{PM}_{2.5}$ concentrations, suggesting that the reduction of solar radiation by aerosol particles has an important impact on the reduction of $\mathrm{O}_{3}$ concentrations. Figure $3 \mathrm{a}$ also shows that the relationship between $\mathrm{O}_{3}$ and $\mathrm{PM}_{2.5}$ was not linearly related. For example, when the concentrations of $\mathrm{PM}_{2.5}$ were less than $100 \mu \mathrm{g} \mathrm{m}^{-3}, \mathrm{O}_{3}$ concentrations rapidly decreased with the increase in $\mathrm{PM}_{2.5}$ concentrations. In contrast, when the concentrations of $\mathrm{PM}_{2.5}$ were greater than $100 \mu \mathrm{g} \mathrm{m}^{-3}, \mathrm{O}_{3}$ concentrations slowly decreased with the increase in $\mathrm{PM}_{2.5}$ concentrations. This is consistent with the result of Bian et al. (2007).

It is interesting to note that from late spring to early fall, the correlation between $\mathrm{PM}_{2.5}$ and $\mathrm{O}_{3}$ concentrations was positive compared to the negative relationship in winter (see Fig. 3b). This result suggests that $\mathrm{O}_{3}$ production was high during the heavy haze period, despite the fact that the solar radiation was greatly depressed. In order to clearly display 


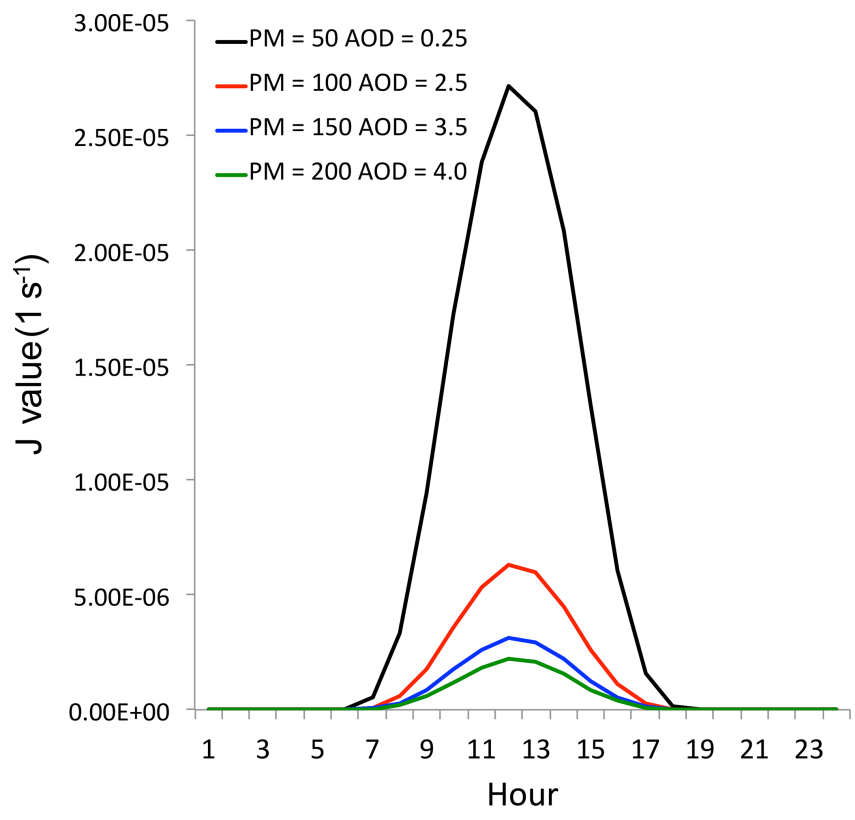

Figure 7. The effect of aerosol levels with $\mathrm{AOD}=0.25$ (black line), $\mathrm{AOD}=2.5$ (red line), $\mathrm{AOD}=3.5$ (blue line), and $\mathrm{AOD}=4.0$ (green line) on the $\mathrm{O}_{3}$ photolysis calculated by the TUV model in October at middle latitudes.

this unusual event, we illustrate diurnal variations of $\mathrm{PM}_{2.5}$, $\mathrm{O}_{3}$, and $\mathrm{NO}_{2}$ during a fall period (from 5 to 6 October 2015). Figure 4 shows that during this period (as a case study), the $\mathrm{PM}_{2.5}$ concentrations were very high, ranging from 150 to $320 \mathrm{\mu g} \mathrm{m}^{-3}$. Under such high aerosol conditions, the solar radiation should be significantly reduced, and $\mathrm{O}_{3}$ photochemical production would also be reduced. However, the diurnal variation of $\mathrm{O}_{3}$ was unexpectedly strong, with a high noontime concentration of $>220 \mu \mathrm{g} \mathrm{m}^{-3}$ and very low nighttime concentration of $\sim 25 \mu \mathrm{g} \mathrm{m}^{-3}$. This strong diurnal variation was due to photochemical activity, which suggested that during relatively low solar conditions, the photochemical activities of $\mathrm{O}_{3}$ production were high. According to the theory of $\mathrm{O}_{3}$ chemical production, high $\mathrm{O}_{3}$ production is related to a high oxidant of $\mathrm{OH}$ (Seinfeld and Pandis, 2006), which should not occur during lower solar radiation. This result brings up an important issue for air pollution control strategies because both $\mathrm{PM}_{2.5}$ and $\mathrm{O}_{3}$ are severe air pollutants in eastern China.

To clearly understand the effect of high aerosol concentrations on solar radiation, we investigate the meteorological conditions, such as cloud cover, relation humidity (RH), and solar radiation, during the period of the case study (see Figs. 5 and 6). Figure 5 shows that the cloud condition was close to cloud-free, but there was a very heavy aerosol layer in the Beijing region, suggesting that cloud cover played a minor role in the reduction of solar radiation. The measured $\mathrm{RH}$ values (not shown) were generally higher than $60 \%$, with a maximum of $95 \%$ during the period. As a result, high aerosol concentrations accompanied by high RH produced important effects on solar radiation. As shown in Fig. 6, the daytime averaged solar radiation was significantly reduced (about a $40 \%$ reduction in the 5-6 October period compared with the value of 8 October).

\section{Methods}

In order to better understand the $\mathrm{O}_{3}$ chemical production that occurred in heavy aerosol conditions in eastern China, the possible $\mathrm{O}_{3}$ production in such conditions is discussed. Ozone photochemical production $\left(P\left[\mathrm{O}_{3}\right]\right)$ is strongly related to the amount of OH radicals (Chameides et al., 1999). According to the traditional theory, the amount of surface $\mathrm{OH}$ radicals is proportional to the surface solar radiation, which is represented by

$[\mathrm{OH}]=P\left[\mathrm{HO}_{x}\right] / L\left[\mathrm{HO}_{x}\right]^{*}$,

where $[\mathrm{OH}]$ represents the concentration of hydroxyl radicals (no. $\mathrm{cm}^{-3}$ ), where "no." represents the number of molecules; $\mathrm{HO}_{x}$ represents the concentration of $\mathrm{HO}_{2}+\mathrm{OH}\left(\right.$ no. $\left.\mathrm{cm}^{-3}\right)$; $P\left[\mathrm{HO}_{x}\right]$ represents the photochemical production of $\mathrm{HO}_{x}$ (no. $\mathrm{cm}^{-3} \mathrm{~s}^{-1}$ ); and $L\left[\mathrm{HO}_{x}\right]^{*}\left(1 \mathrm{~s}^{-1}\right)$ represents the photochemical destruction of $\mathrm{HO}_{x}$, which is normalized by the concentrations of $\mathrm{OH}$.

The major process for the photochemical production of $P\left[\mathrm{HO}_{x}\right]$ is through $\mathrm{O}_{3}$ photolysis and follows the reaction with atmospheric water vapor. It can be expressed as

$$
\begin{aligned}
& P\left[\mathrm{HO}_{x}\right]=J_{1}\left[\mathrm{O}_{3}\right] /\left(k_{1} \times \mathrm{am}\right) \times 2.0 \\
& \quad \times k_{2}\left[\mathrm{H}_{2} \mathrm{O}\right]=P_{1}\left[\mathrm{HO}_{x}\right],
\end{aligned}
$$

where $J_{1}$ represents the photolysis of $\mathrm{O}_{3}+h v \rightarrow \mathrm{O}^{1} \mathrm{D} ; k_{1}$ represents the reaction rate of $\mathrm{O}^{1} \mathrm{D}+\mathrm{am} \rightarrow \mathrm{O}^{3} P$; and $k_{2}$ represents the reaction rate of $\mathrm{O}^{1} \mathrm{D}+\mathrm{H}_{2} \mathrm{O} \rightarrow 2 \mathrm{OH}$. As we can see, this $\mathrm{HO}_{x}$ production is proportional to the magnitude of solar radiation $\left(J_{1}\right)$, and $J_{1}$ is $\mathrm{O}_{3}$ photolysis with solar radiation. Figure 7 shows the relationship between the values of $J_{1}$ and aerosol concentrations in October at middle latitudes calculated by the TUV model (Madronich and Flocke, 1999). This result suggests that under high aerosol concentrations $(\mathrm{AOD}=2.5)$, the $J_{1}$ value is strongly depressed, resulting in a significant reduction of $\mathrm{OH}$ concentrations and $\mathrm{O}_{3}$ production. For example, the maximum $J_{1}$ value is about $2.7 \times 10^{-5}$ $\left(1 \mathrm{~s}^{-1}\right)$ with lower aerosol values $(\mathrm{AOD}=0.25)$. According to a previous study, the surface $\mathrm{PM}_{2.5}$ concentrations were generally smaller than $50 \mu \mathrm{g} \mathrm{m}^{-3}$ with this AOD value (Tie et al., 2017). However, when the AOD value increased to 2.5 (the $\mathrm{PM}_{2.5}$ concentrations are generally $>100 \mu \mathrm{g} \mathrm{m}^{-3}$ ), the maximum $J_{1}$ value rapidly decreased to about $6 \times 10^{-6}$ $\left(1 \mathrm{~s}^{-1}\right)$, which is about a $450 \%$ reduction compared to the value with $\mathrm{AOD}=0.25$. This study suggests that under high $\mathrm{PM}_{2.5}$ concentrations ( $>100 \mu \mathrm{g} \mathrm{m}^{-3}$ ), the photochemical production of $\mathrm{OH}\left(\mathrm{P}\left[\mathrm{HO}_{x}\right]\right)$ is rapidly decreased, leading to low 

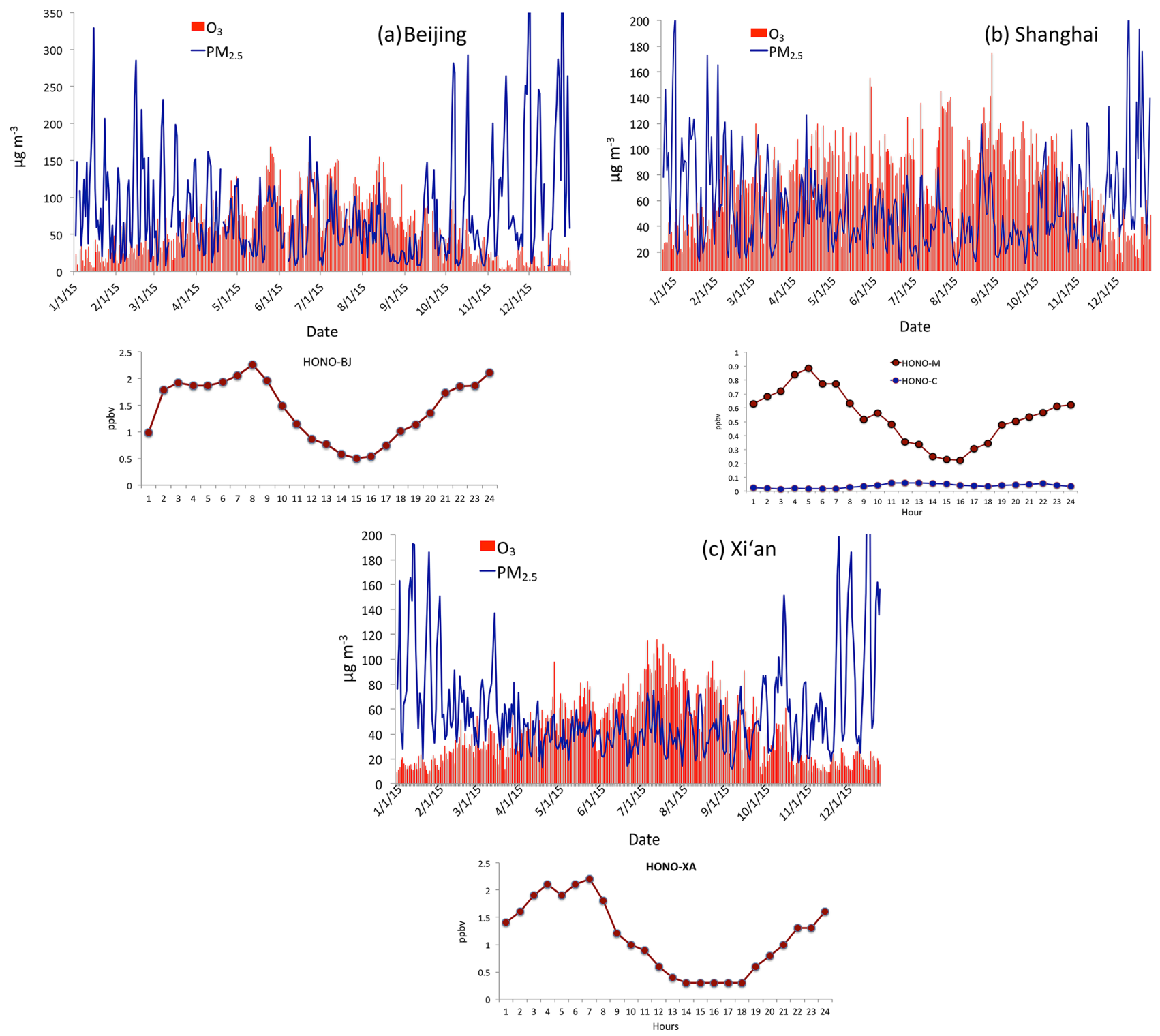

Figure 8. (a) Measured HONO concentrations (ppbv) and $\mathrm{PM}_{2.5}$ and $\mathrm{O}_{3}$ daily concentrations in Beijing. The upper graph shows the measured daily concentrations of $\mathrm{PM}_{2.5}$ and $\mathrm{O}_{3}$ as shown in Fig. 2. The dark red line represents measured HONO in Beijing from 1 to 27 January 2014. (b) Measured HONO concentrations (ppbv) and $\mathrm{PM}_{2.5}$ and $\mathrm{O}_{3}$ daily concentrations in Shanghai. The upper graph shows the measured daily concentrations of $\mathrm{PM}_{2.5}$ and $\mathrm{O}_{3}$ in 2015. The dark red line was measured in Shanghai from 9 to 18 September 2009. The green line was calculated by the WRF-Chem model. (c) Measured HONO concentrations (ppbv) and $\mathrm{PM}_{2.5}$ and $\mathrm{O}_{3}$ daily concentrations in Xi' an. The upper graph shows the measured daily concentrations of $\mathrm{PM}_{2.5}$ and $\mathrm{O}_{3}$ in 2015. The red line represents measured HONO in Xi' An from 24 July to 6 August 2015.

$\mathrm{OH}$ concentrations, which cannot initiate the high oxidation of $\mathrm{O}_{3}$ production. As a result, the high $\mathrm{O}_{3}$ production shown in Fig. 4 cannot be explained. Other sources for $\mathrm{O}_{3}$ oxidation are needed to explain this result.

Recent studies show that HONO concentrations are high in eastern China (R. J. Huang et al., 2017). Under high solar radiation, the photolysis rate of HONO is very high, resulting in very low HONO concentrations in daytime (Seinfeld and Pandis, 2006). These measured high HONO concentra- tions are explained by other studies. One of the explanations is that there are high surface HONO sources during daytime, which produces high HONO concentrations (R. J. Huang et al., 2017). Zhang et al. (2016) suggest that there are several potential HONO sources, including surface emissions and conversion of $\mathrm{NO}_{2}$ at the ocean surface. Zhang et al. (2016) parameterized these potential HONO sources in the WRFChem model, and the calculated HONO concentrations are increased in the WRF-Chem model. 


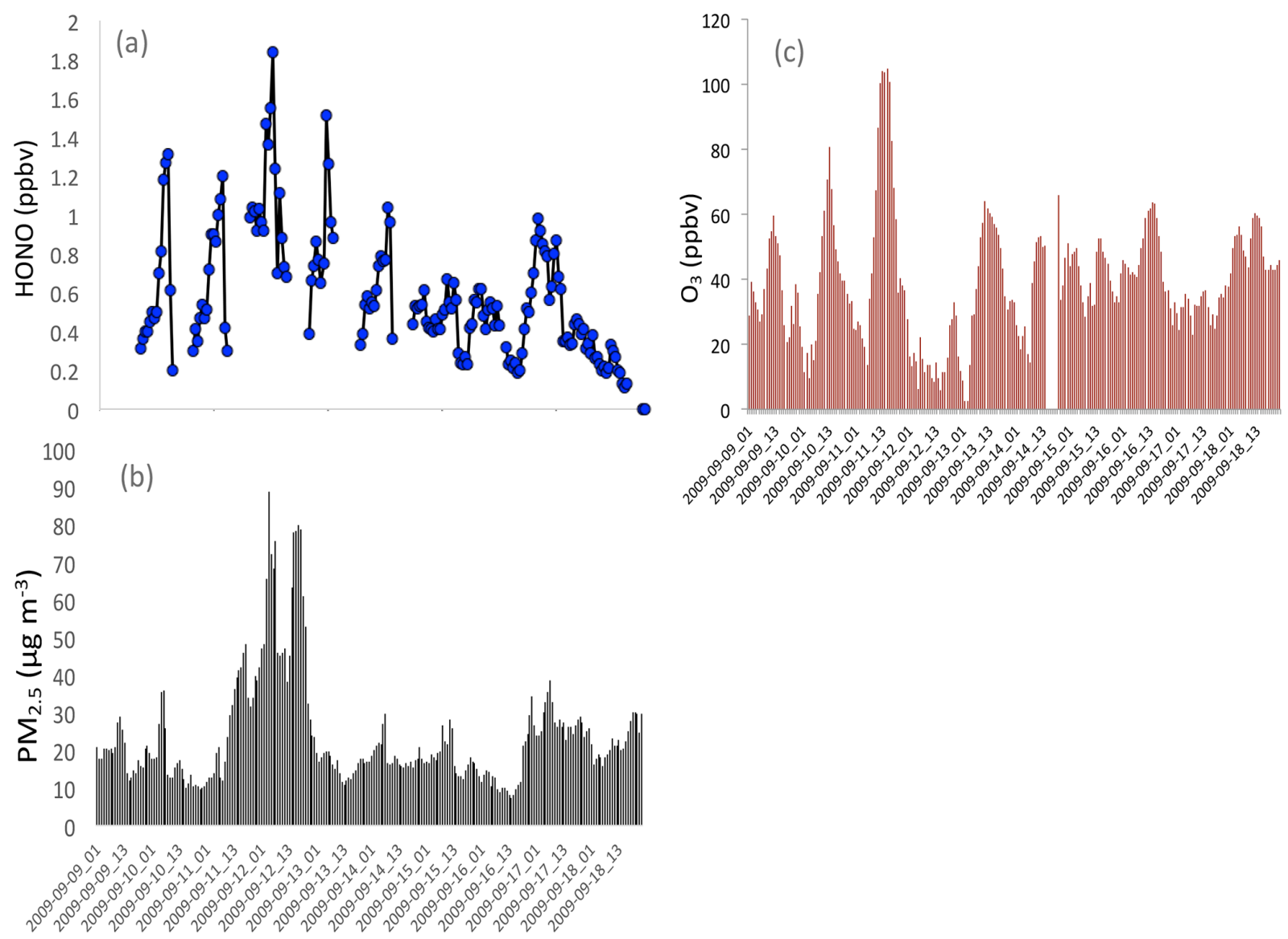

Figure 9. Measured HONO (b), $\mathrm{PM}_{2.5}$ concentrations (c), and $\mathrm{O}_{3}$ concentrations (a) in fall in Shanghai, illustrating that high $\mathrm{HONO}$ concentrations corresponded to high $\mathrm{PM}_{2.5}$ concentrations.

The WRF-Chem model is based on the version developed by Grell et al. (2015) and is improved mainly by Tie et al. (2017) and $\mathrm{Li}$ et al. (2011). The chemical mechanism chosen in this version of WRF-Chem is the RADM2 (Regional Acid Deposition Model, version 2) gas-phase chemical mechanism. For the calculation of HONO, only the gasphase chemistry of $\mathrm{OH}+\mathrm{NO}$ is included to calculate $\mathrm{HONO}$ concentrations. As shown in Fig. 8, the calculated HONO concentrations are significantly smaller than the measured HONO values in eastern China, suggesting that in addition to the gas reaction, there are missing HONO sources (surface sources or others). Because these missing sources are not fully understood and large uncertainty remains, in the following calculation, we compare the $\mathrm{OH}$ concentrations due to both calculated HONO (without the missing sources) and measured HONO concentrations to illustrate the importance of these missing sources for the production of $\mathrm{OH}$ radicals and to suggest that further study is needed to better understand the missing sources; this is an urgent scientific issue.

Figure 8 shows the measured HONO concentrations in three large cities in China (Shanghai, Xi' an, and Beijing) during fall and winter. It also shows the corresponding $\mathrm{PM}_{2.5}$ and $\mathrm{O}_{3}$ in the three cities (i.e., Fig. 8a for Beijing, Fig. $8 \mathrm{~b}$ for Shanghai, and Fig. 8c for Xi' an). It shows that the measured HONO concentrations were high, ranging from smaller than parts per billion measurements to a few parts per billion by volume, with higher values during morning and lower values in daytime. Co-occurrences of high $\mathrm{PM}_{2.5}$ and $\mathrm{O}_{3}$ happened in the three cities. As a result, we think that the high HONO is a common event in large cities in eastern China, especially in daytime. This high HONO is also measured by previous studies (Zhang et al., 2016; Huang et al., 2017). In this study, we make an assumption that the co-occurrence between $\mathrm{O}_{3}$ and $\mathrm{PM}_{2.5}$ occurred under high HONO concentrations. We note that using this assumption may result in some uncertainties in estimating the effect of HONO on OH. For example, using the measured HONO in Xi' an and Beijing could produce 1-2 times higher $\mathrm{OH}$ production by the photolysis of HONO than the result by using the data from Shanghai. In this case, we use the measured HONO from Shanghai to avoid overestimating the HONO effect, which can be considered a low-limit estimation.

It is also interesting to note that high HONO concentrations occurred during high aerosol concentration periods. 

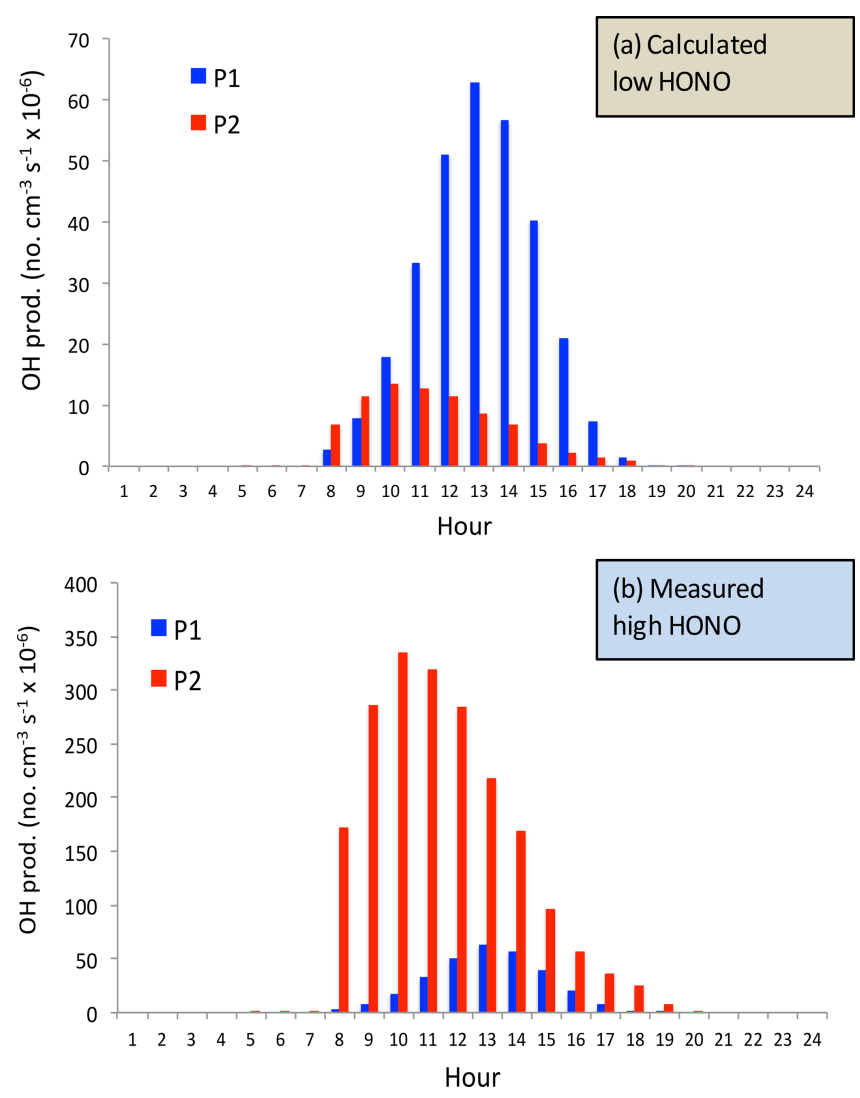

Figure 10. The calculated $\mathrm{OH}$ production $P\left(\mathrm{HO}_{x}\right)\left(\right.$ no. $\left.\mathrm{cm}^{-3} \mathrm{~s}^{-1}\right)$ by using the model-calculated HONO (low concentrations) (a) and by using the measured HONO (high concentrations) (b). The blue bars represent the calculation of the $P_{1}$ term, and the red bars represent the calculation of the $P_{2}$ term $(\mathrm{OH}$ production from $\mathrm{HONO})$.

Figure 9 illustrates that when the $\mathrm{PM}_{2.5}$ concentrations increased to $70-80 \mu \mathrm{g} \mathrm{m}^{-3}$, the HONO concentrations were enhanced to 1.4-18 ppbv during September in Shanghai. These measured HONO concentrations were significantly higher than the calculated concentrations (shown in Fig. 8), suggesting that some additional sources of HONO are needed. This result is consistent with HONO measurements in other Chinese cities (Huang et al., 2017).

High HONO concentrations in daytime are becoming a significant source of $\mathrm{OH}$ radicals. As a result, the $\mathrm{OH}$ production rate $\left(P\left[\mathrm{HO}_{x}\right]\right)$ can be written according to the following reactions.

$$
\begin{aligned}
P_{2}\left[\mathrm{HO}_{x}\right] & =J_{2} \times[\mathrm{HONO}] \\
P\left[\mathrm{HO}_{x}\right] & =P_{1}\left[\mathrm{HO}_{x}\right]+P_{2}\left[\mathrm{HO}_{x}\right] \\
& =J_{1}\left[\mathrm{O}_{3}\right] /\left(k_{1} \times \mathrm{am}\right) \times 2.0 \times k_{2}\left[\mathrm{H}_{2} \mathrm{O}\right] \\
& +J_{2} \times[\mathrm{HONO}]
\end{aligned}
$$

Because the chemical lifetime of $\mathrm{OH}$ is less than a second, $\mathrm{OH}$ concentrations can be calculated according to the equilibrium of chemical production and chemical loss. With
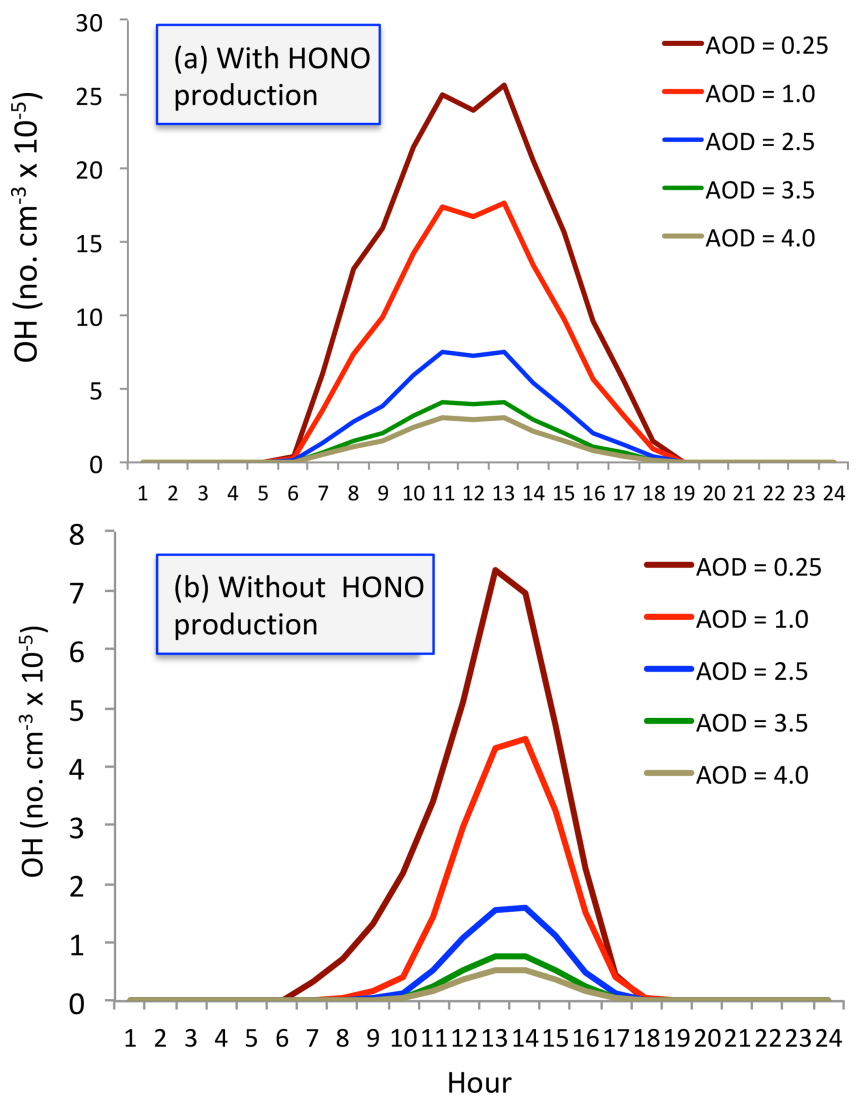

Figure 11. The calculated $\mathrm{OH}$ concentrations (no. $\mathrm{cm}^{-3}$ ) with (a) and without (b) HONO production of $\mathrm{OH}$ under different aerosol levels. Dark red $(\mathrm{AOD}=0.25)$, red $(\mathrm{AOD}=1.0)$, blue $(\mathrm{AOD}=2.5)$, green $(\mathrm{AOD}=3.5)$, and beige $(\mathrm{AOD}=4.0)$.

both $\mathrm{OH}$ chemical production processes, the $\mathrm{OH}$ concentrations can be calculated by the following equation (Seinfeld and Pandis, 2006):

$P_{1}+P_{2}=L_{1}+L_{2}$

where $P_{1}$ and $P_{2}$ represent the major chemical production expressed in Reaction (R4), and $L_{1}$ and $L_{2}$ are the major chemical loss of $\mathrm{OH}$ represented by

$L_{1}: \mathrm{OH}+\mathrm{NO}_{2} \rightarrow \mathrm{HNO}_{3}$,

$L_{2}: \mathrm{HO}_{2}+\mathrm{HO}_{2} \rightarrow \mathrm{H}_{2} \mathrm{O}_{2}+\mathrm{O}_{2}$.

Under high $\mathrm{NO}_{x}$ conditions, such as in the large cities in eastern China, $\mathrm{NO}_{x}$ concentrations were often higher than 50 ppbv (as shown in Fig. 4). As a result, the $L_{1}$ term is larger than $L_{2}$. The $\mathrm{OH}$ concentrations can be approximately expressed as

$$
\begin{aligned}
& {[\mathrm{HO}]=\left\{J_{1}\left[\mathrm{O}_{3}\right] /\left(k_{1} \times \mathrm{am}\right) \times 2.0 \times k_{2}\left[\mathrm{H}_{2} \mathrm{O}\right]\right.} \\
& \left.\quad+J_{2} \times[\mathrm{HONO}]\right\} / k_{3}\left[\mathrm{NO}_{2}\right],
\end{aligned}
$$

where $k_{3}$ is the reaction coefficient of $\mathrm{OH}+\mathrm{NO}_{2} \rightarrow \mathrm{HNO}_{3}$. 

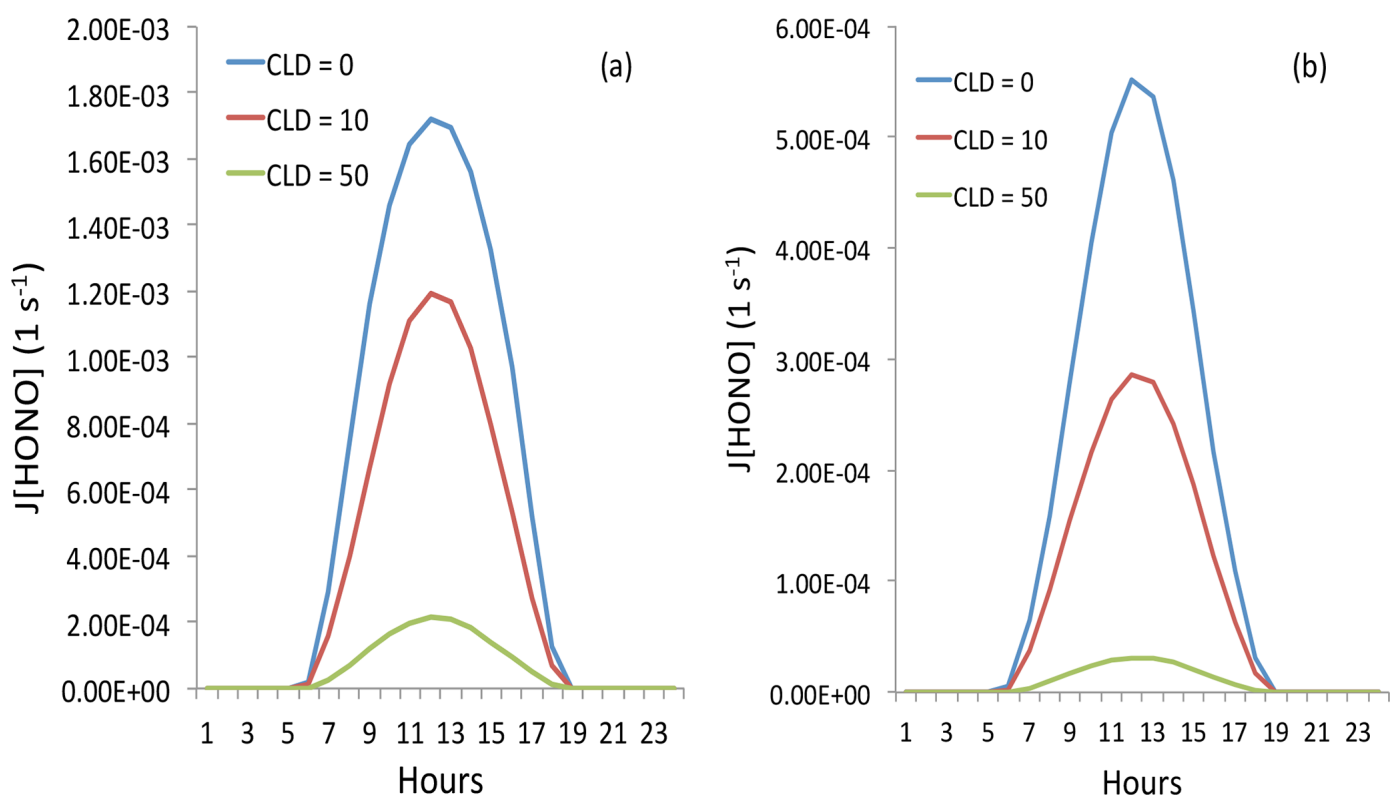

Figure 12. The effect of cloud cover on the photolysis rate of HONO ( $J[\mathrm{HONO}])$. The blue, red, and green lines represent cloud water vapor of $0 \mathrm{~g} \mathrm{~m}^{-3}$ (cloud-free), $10 \mathrm{~g} \mathrm{~m}^{-3}$ (thin cloud), and $50 \mathrm{~g} \mathrm{~m}^{-3}$ (thick cloud), respectively. Panel (a) represents light aerosol conditions with an AOD of 0.25 , and panel (b) represents heavy aerosol conditions with an AOD of 2.5.

\section{Results and analysis}

\subsection{OH production in different HONO conditions}

In order to quantify the individual effects of these two $\mathrm{OH}$ production terms $\left(P_{1}\right.$ and $\left.P_{2}\right)$ on the $\mathrm{OH}$ concentrations, $P_{1}$ and $P_{2}$ are calculated under different daytime HONO conditions (calculated low HONO and measured high HONO concentrations). Figure 10 shows that under low HONO conditions, $P_{1}$ is significantly higher than $P_{2}$, and $P_{2}$ has only a minor contribution to the $\mathrm{OH}$ values. For example, the maximum of $P_{1}$ occurred at 13:00 CST, with a value of $65 \times 10^{6}$ no. $\mathrm{cm}^{-3} \mathrm{~s}^{-1}$. In contrast, the maximum of $P_{2}$ occurred at 10:00 CST, with a value of $15 \times 10^{6}$ no. $\mathrm{cm}^{-3} \mathrm{~s}^{-1}$. However, under high HONO conditions, $P_{2}$ plays very important roles for $\mathrm{OH}$ production. The maximum of $P_{2}$ occurred at 11:00 CST, with a value of $350 \times 10^{6}$ no. $\mathrm{cm}^{-3} \mathrm{~s}^{-1}$, which is about $500 \%$ higher than the $P_{1}$ value. It is important to note that this calculation is based on high aerosol conditions $(\mathrm{AOD}=2.5)$ in September. This result can explain the high $\mathrm{O}_{3}$ chemical production in Fig. 4.

\section{2 $\mathrm{OH}$ in different aerosol conditions}

We seek to understand the effect of aerosol conditions, especially high aerosol conditions, on $\mathrm{OH}$ concentrations. Figure 11 shows $\mathrm{OH}$ concentrations with and without the $\mathrm{HONO}$ production of $\mathrm{OH}$. With including the HONO production (i.e., including $P_{1}$ and $P_{2}$ ), the calculated $\mathrm{OH}$ concentrations are significantly higher than without including this production (i.e., only including $P_{1}$ ). Both calculated $\mathrm{OH}$ concen- trations are rapidly changed with different levels of aerosol conditions. For example, without HONO production, the maximum $\mathrm{OH}$ concentration is about $7.5 \times 10^{5} \mathrm{no} . \mathrm{cm}^{-3}$ under low aerosol conditions $(\mathrm{AOD}=0.25)$. In contrast, the maximum $\mathrm{OH}$ concentration was rapidly reduced to $1.5 \times$ $10^{5}$ no. $\mathrm{cm}^{-3}$ under high aerosol conditions $(\mathrm{AOD}=2.5)$ and further decreased to $1.0 \times 10^{5}$ no. $\mathrm{cm}^{-3}$ with the AOD value of 3.5. In contrast, with including $\mathrm{HONO}$ production, the $\mathrm{OH}$ concentrations significantly increased. Under higher aerosol conditions $(\mathrm{AOD}=2.5)$, the maximum $\mathrm{OH}$ concentration is about $7.5 \times 10^{5}$ no. $\mathrm{cm}^{-3}$, which is the same value under low aerosol conditions in the no-HONO case. This result suggests that measured high $\mathrm{O}_{3}$ production occurring in high aerosol conditions is likely due to the high HONO concentrations in Shanghai.

\subsection{Effects of clouds}

Cloud cover can have very important impacts on the photolysis of HONO, which can affect the effect of HONO on $\mathrm{OH}$ radicals. The above calculations are based on cloud-free conditions, with a heavy aerosol concentration in the Beijing region. As shown in Fig. 5, during the case study period (5 to 6 October 2015) (see Fig. 4), the weather map shows cloudfree conditions with heavy aerosol conditions.

In order to understand the effects of cloud on the photolysis of HONO, we include different cloud cover in the TUV model. The calculated results are shown in Fig. 12. The results show that thin cloud (with cloud cover at $2 \mathrm{~km}$ and cloud water of $10 \mathrm{~g} \mathrm{~m}^{-3}$ ) could reduce the photolysis rate of HONO by about $40 \%$, but the HONO could still have important 
effects. However, with dense cloud conditions (with cloud cover at 2 and $3 \mathrm{~km}$ and cloud water of 50 and $10 \mathrm{~g} \mathrm{~m}^{-3}$ ), the photolysis rate of HONO could be reduced by 9-10 times by the cloud. In this case, adding the photolysis rate of HONO cannot produce an important effect on $\mathrm{OH}$ radicals and the production of $\mathrm{O}_{3}$.

\section{4 $\mathrm{OH}$ in winter}

The measurement of $\mathrm{O}_{3}$ also shows that the concentrations in winter were always low (see Fig. 2), suggesting that the $\mathrm{O}_{3}$ concentrations were not significantly affected by the appearance of HONO. Figure 13 shows the $\mathrm{OH}$ concentrations in September and December. It shows that under different aerosol conditions, $\mathrm{OH}$ concentrations in December were very low compared with the values in September. Both the calculated $\mathrm{OH}$ concentrations include the HONO production term. For example, under the condition of $\mathrm{AOD}=2.5$, the maximum $\mathrm{OH}$ is about $7.5 \times 10^{5}$ no. $\mathrm{cm}^{-3}$ in September, while it is rapidly reduced to $1.5 \times 10^{5}$ no. $\mathrm{cm}^{-3}$ in December. Under the condition of $\mathrm{AOD}=3.5$, the maximum $\mathrm{OH}$ is still maintained at a relatively high level $\left(4.5 \times 10^{5}\right.$ no. $\left.\mathrm{cm}^{-3}\right)$ in September. However, the maximum $\mathrm{OH}$ values are extremely low in December, with maximum value of $0.5 \times$ $10^{5}$ no. $\mathrm{cm}^{-3}$. Because both types of $\mathrm{OH}$ chemical production $\left(P_{1}\right.$ and $\left.P_{2}\right)$ are strongly dependent upon solar radiation (see Reaction R4), the seasonal variation of solar radiation plays important roles for controlling the $\mathrm{OH}$ production in winter (see Fig. 13). Because the solar radiation is at a very low level in winter, adding the photolysis of HONO has a smaller effect in winter than in other seasons, and $\mathrm{OH}$ remains at low values by including the HONO production term.

\section{Summary}

Currently, China is undergoing rapid economic development, resulting in a high demand for energy and greater use of fossil fuels. As a result, high emissions of pollutants produce heavy aerosol pollution $\left(\mathrm{PM}_{2.5}\right)$ in eastern China, such as in the megacity of Beijing. Long-term measurements show that in addition to heavy aerosol pollution, $\mathrm{O}_{3}$ is becoming another major pollutant in the Beijing region. The measured results show that there was very strong seasonal variation in the concentrations of both $\mathrm{PM}_{2.5}$ and $\mathrm{O}_{3}$ in the region. During winter, the seasonal variability of $\mathrm{O}_{3}$ concentrations was anticorrelated with $\mathrm{PM}_{2.5}$ concentrations. However, from late spring to early fall, the correlation between $\mathrm{PM}_{2.5}$ and $\mathrm{O}_{3}$ concentrations was positive compared to negative in winter. This result suggests that during heavy aerosol conditions (solar radiation was depressed), the $\mathrm{O}_{3}$ chemical production was still high, appearing as a co-occurrence of high $\mathrm{PM}_{2.5}$ and $\mathrm{O}_{3}$ in some cases from late spring to early fall. This cooccurrence of high $\mathrm{PM}_{2.5}$ and $\mathrm{O}_{3}$ is the focus of this study. The results are highlighted as follows.
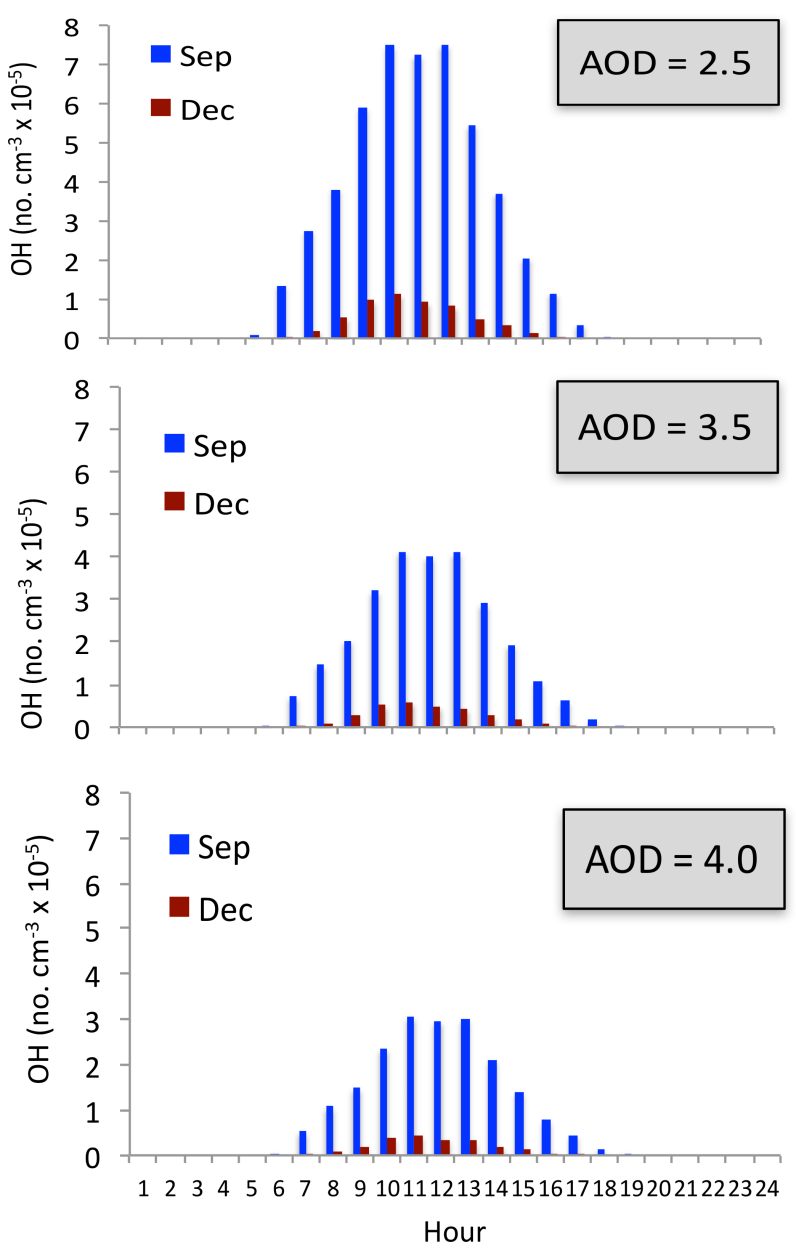

Figure 13. The calculated $\mathrm{OH}$ concentrations in September (blue bars) and December (dark red bars) under different aerosol levels.

1. There are high daytime HONO concentrations in major Chinese megacities, such as Beijing and Shanghai. It is also interesting to note that high HONO concentrations occurred during high aerosol concentration periods. Under high daytime HONO concentrations, HONO can be photodissociated to $\mathrm{OH}$ radicals and become an important part of the process to produce $\mathrm{OH}$.

2. With including the $\mathrm{OH}$ production of measured $\mathrm{HONO}$ concentrations, the calculated $\mathrm{OH}$ concentrations are significantly higher than without including this production. For example, without HONO production, the maximum $\mathrm{OH}$ concentration is about $7.5 \times 10^{5}$ no. $\mathrm{cm}^{-3}$ under low aerosol conditions $(\mathrm{AOD}=0.25)$ and is rapidly reduced to $1.5 \times 10^{5}$ no. $\mathrm{cm}^{-3}$ under high aerosol conditions $(\mathrm{AOD}=2.5)$ in September. In contrast, by including $\mathrm{HONO}$ production, the $\mathrm{OH}$ concentrations significantly increased. For example, under higher aerosol conditions $(\mathrm{AOD}=2.5)$, the maximum $\mathrm{OH}$ concentration is about $7.5 \times 10^{5}$ no. $\mathrm{cm}^{-3}$, which is similar to the value under low aerosol conditions in the no-HONO 
case. This result suggests that even under high aerosol conditions, the chemical oxidizing process for $\mathrm{O}_{3}$ production can be active. This result is likely to explain the co-occurrence of high $\mathrm{PM}_{2.5}$ and high $\mathrm{O}_{3}$ from late spring to early in eastern China.

3. The measurement of $\mathrm{O}_{3}$ also shows that the concentrations in winter were always low, suggesting that the $\mathrm{O}_{3}$ concentrations were not significantly affected by the appearance of HONO. The calculated result shows that the seasonal variation of solar radiation plays important roles for controlling the $\mathrm{OH}$ production in winter. Because solar radiation is at a very low level in winter, adding the photolysis of HONO has a smaller effect in winter than in other seasons, and $\mathrm{OH}$ remains at low values by including the HONO production term.

In recent years, $\mathrm{PM}_{2.5}$ pollution has been reduced due to the large control efforts by the Chinese government, but $\mathrm{O}_{3}$ pollution has become another severe pollution problem in eastern China. This study is important because it provides some significant scientific insight to better understand $\mathrm{O}_{3}$ pollution in eastern China.

Data availability. The data used in this paper can be provided upon request from Xuexi Tie (tiexx@ieecas.cn).

Author contributions. XT came up with the original idea of investigating the scientific issue. XT and JX designed the analysis method. XL, GL, JC, and SZ provided the observational data and helped in discussion. XT prepared the paper with contributions from all coauthors.

Competing interests. The authors declare that they have no conflict of interest.

Acknowledgements. This work was supported by the National Natural Science Foundation of China (NSFC) under grant nos. 41430424 and 41730108 . The authors are grateful for support from the Center for Excellence in Urban Atmospheric Environment, Institute of Urban Environment, Chinese Academy of Sciences.

Financial support. This research has been supported by the National Natural Science Foundation of China (grant nos. 41430424 and 41730108).

Review statement. This paper was edited by Jianping Huang and reviewed by two anonymous referees.

\section{References}

Bian, H., Han, S. Q., Tie, X., Shun, M. L., and Liu, A. X.: Evidence of Impact of Aerosols on Surface Ozone Concentration: A Case Study in Tianjin, China, Atmos. Environ., 41, 4672-4681, 2007.

Chameides, W. L., Fehsenfeld, F., Rodgers, M. O., Cardelino, C., Martines, J., Parrish, D., Lonneman, W., Lawson, D. R., Rasmussen, R. A., Zimmerman, P., Greenberg, J., Middleton, P., and Wang, T.: Ozone precursor relationships in the ambient atmosphere, J. Geophys. Res., 97, 6037-6055, 1992.

Deng, X. J, Tie, X., Wu, D., Zhou, X. J., Tan, H. B., Li, F., and Jiang, C.: Long-term trend of visibility and its characterizations in the Pearl River Delta Region (PRD), China, Atmos. Environ., 42, 1424-1435, 2008.

Geng, F. H., Zhao, C. S., Tang, X., Lu, G. L., and Tie, X.: Analysis of ozone and VOCs measured in Shanghai: A case study, Atmos. Environ., 41, 989-1001, 2007.

Geng, F. H., Cai, C. G., Tie, X., Yu, Q., An, J. L., Peng, L., Zhou, G. Q., and Xu, J. M.: Analysis of VOC emissions using PCA/APCS receptor model at city of Shanghai, China, J. Atmos. Chem., 62, 229-247, https://doi.org/10.1007/s10874-010-9150-5, 2010.

Grell, G. A., Peckham, S. E., Schmitz, R., McKeen, S. A., Frost, G., Skamarock, W. C., and Eder, B.: Fully coupled "online" chemistry within the WRF model, Atmos. Environ., 39, 6957-6975, 2005.

He, S. and Carmichael, G. R.: Sensitivity of photolysis rates and ozone production in the troposphere to aerosol properties, J. Geophys. Res.-Atmos., 104, 26307-26324, 1999.

Huang, J. P., Li, Y., Fu, C., Chen, F., Fu Q., Dai, A., Shinoda, M., Ma, Z., Guo, W., Li, Z., Zhang, L., Liu, Y., Yu, H., He, Y., Xie, Y., Guan, X., Ji, M., Lin, L., Wang, S., Yan, H., and Wang, G., Dryland climate change recent progress and challenges, Rev. Geophys., 55, 719-778, https://doi.org/10.1002/2016RG000550, 2017.

Huang, J. P, Liu, X. Y., Li, C. Y., Ding, L., and Yu, H. P.: The global oxygen budget and its future projection, Science Bull., 63, 1180 1186, 2018.

Huang, R. J., Yang, L., Cao, J. J., Wang, Q. Y., Tie, X., Ho, K. F., Shen, Z., Zhang, R., Li, G., Zhu, C., Zhang, N., Dai, W., Zhou, J., Liu, S., Chen, Y., Chen, J., and O'Dowd, C. D.: Concentration and sources of atmospheric nitrous acid (HONO) at an urban site in Western China, Sci. Total Environ., 593/594, 165-172, https://doi.org/10.1016/j.scitotenv.2017.02.166, 2017.

Jia, R., Luo, M., Liu, Y., Zhu, Q. Z., Hua, S., Wu, C. Q., and Shao, T.: Anthropogenic Aerosol Pollution over the Eastern Slope of the Tibetan Plateau, Adv. Atmos. Sci., 36, 847-862, 2019.

Lei, W., Zhang, R., Tie, X., and Hess, P.: Chemical characterization of ozone

formation in the Houston-Galveston area, J. Geophys. Res., 109, 1-15, https://doi.org/10.102/2003JD004219, 2004.

Li, G., Bei, N., Tie, X., and Molina, L. T.: Aerosol effects on the photochemistry in Mexico City during MCMA2006/MILAGRO campaign, Atmos. Chem. Phys., 11, 51695182, https://doi.org/10.5194/acp-11-5169-2011, 2011.

Li, G., Bei, N., Cao, J., Wu, J., Long, X., Feng, T., Dai, W., Liu, S., Zhang, Q., and Tie, X.: Widespread and persistent ozone pollution in eastern China during the non-winter season of 2015: observations and source attributions, Atmos. Chem. Phys., 17, 2759-2774, https://doi.org/10.5194/acp-17-2759-2017, 2017. 
Long, X., Tie, X., Cao, J., Huang, R., Feng, T., Li, N., Zhao, S., Tian, J., Li, G., and Zhang, Q.: Impact of crop field burning and mountains on heavy haze in the North China Plain: a case study, Atmos. Chem. Phys., 16, 9675-9691, https://doi.org/10.5194/acp-16-9675-2016, 2016.

Madronich, S. and Flocke, S.: The Role of Solar Radiation in Atmospheric Chemistry, in: Environmental Photochemistry 2/2L, 1-26, Springer Berlin Heidelberg, 1-26, 1999.

Quan, J. N., Gao, Y., Zhang, Q., Tie, X., Cao, J. J., Han, S. Q., Meng, J. M., Chen, P. F., and Zhao, D. L.: Evolution of Planetary Boundary Layer under different weather conditions, and its impact on aerosol concentrations, Particuology, 11, 34-40, https://doi.org/10.1016/j.partic.2012.04.005, 2013.

Seinfeld, J. H. and Pandis, S. N.: Atmospheric Chemistry and Physics, From Air Pollution to Climate Change, 2nd Edn., John Wiley and Sons, New York, chap. 6, Chemistry of the Troposphere, 204-274, 2006.

Sillman, S.: The use of $\mathrm{NO}_{y}, \mathrm{H}_{2} \mathrm{O}_{2}$, and $\mathrm{HNO}_{3}$ as indicators for ozone- $\mathrm{NO}_{x}$-hydrocarbon sensitivity in urban locations, J. Geophys. Res., 100, 14175-14188, 1995.

Tie, X. and Cao, J. J.: Understanding Variability of Haze in Eastern China, J. Fundam. Renew. Energ. Appl., 7, 1-4, https://doi.org/10.4172/2090-4541.1000241, 2017.

Tie, X., Brasseur, G., Zhao, C., Granier, C., Massie, S., Qin, Y., Wang, P. C., Wang, G. L., and Yang, P. C.: Chemical Characterization of Air Pollution in Eastern China and the Eastern United States, Atmos. Environ., 40, 2607-2625, 2006.

Tie, X., Wu, D., and Brasseur, G.: Lung Cancer Mortality and Exposure to Atmospheric Aerosol Particles in Guangzhou, China, Atmos. Environ., 43, 2375-2377, 2009a.

Tie, X., Geng, F. H., Peng, L., Gao, W., and Zhao, C. S.: Measurement and modeling of $\mathrm{O}_{3}$ variability in Shanghai, China; Application of the WRF-Chem model, Atmos. Environ., 43, 42894302, 2009b.
Tie, X., Geng, F., Guenther, A., Cao, J., Greenberg, J., Zhang, R., Apel, E., Li, G., Weinheimer, A., Chen, J., and Cai, C.: Megacity impacts on regional ozone formation: observations and WRFChem modeling for the MIRAGE-Shanghai field campaign, Atmos. Chem. Phys., 13, 5655-5669, https://doi.org/10.5194/acp13-5655-2013, 2013.

Tie, X., Zhang, Q., He, H., Cao, J. J., Han, S.Q., Gao, Y., Li, X., and Jia, X. C.: A budget analysis on the formation of haze in Beijing, Atmos. Environ., 100, 25-36, https://doi.org/10.1016/j.atmosenv.2014.10.038, 2015.

Tie, X., Huang, R. J., Dai, W. T., Cao, J. J., Long, X., Su, X. L., Zhao, S. Y., Wang, Q. Y., and Li, G. H.: Effect of heavy haze and aerosol pollution on rice and wheat productions in China, Sci. Rep., 6, 29612, https://doi.org/10.1038/srep29612, 2016.

Tie, X., Huang, R. J., Cao, J. J., Zhang, Q., Cheng, Y. F., Su, H., Chang, D., Pöschl, U., Hoffmann, T., Dusek, U., Li, G. H., Worsnop, D. R., and O'Dowd, C. D.: Severe Pollution in China Amplified by Atmospheric Moisture, Sci. Rep., 7, 15760, https://doi.org/10.1038/s41598-017-15909-1, 2017.

Zhang, L., Wang, T., Zhang, Q., Zheng, J., Xu, Z., and Lv, M.: Potential sources of nitrous acid (HONO) and their impacts on ozone: A WRF/Chem study in a polluted subtropical region, J. Geophys. Res.-Atmos., 121, 3645-3662, 2016.

Zhang, Q., Zhao, C. S., Tie, X., Wei, Q., Li, G. H., and Li, C.: Characterizations of Aerosols over the Beijing Region: A Case Study of Aircraft Measurements, Atmos. Environ., 40, 45134527, 2006.

Zhang, R., Tie, X., and Bond, D.: Impacts of Anthropogenic and Natural $\mathrm{NO}_{x}$ Sources over the US on Tropospheric Chemistry, P. Natl. Acad. Sci. USA, 100, 1505-1509, 2003.

Zhu, Q., Liu, Y., Jia, R., Hua, S., Shao, T., and Wang, B.: A numerical simulation study on the impact of smoke aerosols from Russian forest fires on the air pollution over Asia, Atmos. Environ., 182, 263-274, 2018. 